a complete set of Rules-so designated-may prompt the court to act in the future. If the court does act, a more flexible procedure should result.

\title{
CONCLUSIONS
}

Despite the efforts of the draftsmen to construct a bill that will state the law precisely and simply, yet, if the bill be enacted, a period of substantial confusion of the law will follow. Since most of the sections are adaptations of existing law in this or other states, and since those provisions have already been construed by the courts, the period of confusion will, perhaps, not be as protracted nor as intense as might be expected.

It is reasonable to suppose that following the period of construction there will be a simplification of many of the problems now encountered in our procedure in civil cases. The proposed act is wholesome and far-reaching, and indicates a thorough consideration of the problems of practice from a practical as well as a theoretical standpoint.

It is also quite likely that the proposed act will produce an improvement in judicial administration, particularly in the field of trial practice. Undoubtedly, pleading problems will be greatly simplified. The enactment of the proposed bill will produce, in form at least, an extension, to the common law field, of simplified forms of equity pleading now generally employed in Illinois.

\section{REORGANIZATION OF RAILROADS UNDER THE BANKRUPTCY ACT}

\section{LIOYD K. GARRISON*}

$\mathrm{B}^{\mathrm{r}}$ Y THE Act of March 3, I933 ${ }^{\mathrm{I}}$ three new forms of procedure for the relief of debtors were added to the Bankruptcy Act. ${ }^{2}$ The most important of these (Section 77) relates to the reorganization of railroads engaged in interstate commerce. ${ }^{3}$ In every respect this section is unique in the history of our legislation.

It brings railroads, for the first time, within the scope of the Bankruptcy Act. It represents the first attempt in this country 4 to provide a statutory method for

* Dean, the University of Wisconsin Law School.

I Public-no. 420-72d Congress [H.R. I4359].

2 The Act of July $\mathrm{r}, \mathrm{I} 898$, as amended [II U.S.C.].

3 The statute excludes $(\$ 77 \mathrm{r})$ any "street, suburban, or interurban electric railway which is not operated as a part of a general railroad system of transportation or which does not derive more than $5 \circ$ per centum of its operating revenues from the transportation of freight in standard steam railroad freight equipment."

4 Since 1870 England has had a reorganization statute. In its original form it provided that a plan affecting a given class of creditors could be made binding upon the consent of a majority in number representing three-fourths in value of the creditors of such class. In Igoo the statute was enlarged by the adoption of a similar provision relating to stockholders. For 
reorganization embracing both creditors and stockholders. It probably goes further than any other statute in the extent to which, in a proceeding commenced and terminated in court, responsibilities and power are given to a commission (the Interstate Commerce Commission). It is also unlike any other statute in the extent to which the functions of court and commission are made interacting and interdependent. In enabling two-thirds of the holders of mortgage bonds to compel the minority to take unsecured obligations or even stock in place of their bonds, it affects securities in a way never before attempted in this country. And in further providing that the debtor's property shall not be liquidated, that the debtor shall not be adjudged or even called a "bankrupt," and that the interests of stockholders as well as the claims of creditors may be dealt with, it represents the furthest limit of power which Congress has ever presumed to exercise under the "bankruptcy clause" of the Constitution. ${ }^{5}$

The legislation is as important economically as it is novel in form. Some fifty or more railroads are now in receivership, awaiting reorganization. ${ }^{6}$ According to authoritative statements in Congress, loans totalling about $\$ 300,000,000$ have already been made to railroads by the Reconstruction Finance Corporation and have not been repaid; 7 applications for loans totalling more than \$roo,$\infty, 0,000$ are pending and probably will not be granted; ${ }^{8}$ and, in the face of dwindling revenues and mounting deficits, some $\$ 300,000,000$ of railroad obligations will shortly be maturing. 9 Under these circumstances wholesale reorganization of capital structures would seem to be inevitable. Hitherto the only process for effecting such reorganization has been the equity receivership,- -generally, and in the case of interstate railroads universally, brought about in the Federal

the latest form of the statute see the Companies Act, I929, I9-20 Geo. 5, C. 23, $\$$ I53 to I55; and Sophian, The Companies Act, 1929. The Canadian Bankruptcy Act contains a reorganization section modelled on the English Companies Act (Act of July 7 , I919, 9-10 Geo. 5, c. 36, $\S \mathrm{r}_{3}$ as amended by Act of June $28, \mathrm{x}_{222}, \mathrm{I}_{2}-\mathrm{r}_{3} \mathrm{Geo} .5$ ).

5 Section 8, Article I ("Congress shall have power . . . . to establish . . . . uniform laws on the subject of bankruptcies"). The new legislation seems unquestionably to fall within this grant of power. See the "Memorandum by the Solicitor General relative to S. 3866 and H.R. 9968, to amend the Bankruptcy Act" (Senate Committee Print, 72d Cong. 2d Sess. Also printed in 76 Cong. Rec., $72 \mathrm{~d}$ Cong., 2d Sess., 29r2). See also Rosenberg, A New Scheme of

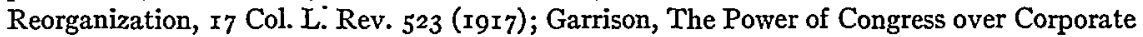
Reorganizations, ig Va. L. Rev. 343 (I933).

${ }^{6}$ See Moody, Steam Railroads (I932), A I8; Moody, Manual for Steam Railroads (I932), 866; and the Annual Report of the Interstate Commerce Commission for I932, pp. I5, I6, quoted by Swaine, Corporate Reorganization under the Federal Bankruptcy Power, rg Va. L. Rev. 317, 318 (1933).

${ }_{7} 76$ Cong. Rec., 72 d Cong., 2d Sess. 525I (by Sen. Hastings, Feb. 27, r933), and 5270 (by Sen. Couzens, Feb. 27, I933).

${ }^{8}$ Ibid., 5269 (by Sen. Couzens, Feb. 27, r933); and 2898 (from the House Judiciary Committee report on the bill, Jan. 28 , I933, stating that the railroads generally "have reached the limit of their ability to borrow from the R.F.C."').

9 By Sen. Hastings, 76 Cong. Rec., 72d Cong., 2d Sess. 525I (I933). 
courts. The waste, delay and inefficiency of this process, and the opportunities for exploitation which it sometimes affords have long been notorious; and such success as it has achieved has been increasingly threatened by proposed legis'ation $^{\text {To }}$ that would limit or abolish diversity of citizenship as a ground for Federal jurisdiction. Hence the importance of the new procedure, which, it is hoped, will proyide an economical, expeditious and effective method of reorganization adequately protected against abuse, and based upon a sure jurisdictional foundation.

The procedure under Section 77 , and the respects in which it remedies existing defects may be outlined as follows:

A railroad may file a petition stating that it is insolvent or unable to meet its debts as they mature and that it desires to effect a plan of reorganization..$^{\text {II }}$ Or, with the approval of the Interstate Commerce Commission, after a hearing upon notice to the railroad, creditors with claims aggregating $5 \%$ of its indebtedness ${ }^{12}$ may file a petition against the railroad alleging that it is unable to meet its debts and that a reorganization should be effected. The railroad's only defenses to such a petition are that the creditors' claims are insufficient or that the road is solvent. Upon approving the petition (whether voluntary or involuntary) the court may appoint a temporary trustee and, after a hearing upon notice to creditors and stockholders, a permanent trustee, selected in either case from a panel of standing trustees to be designated by the commission. ${ }^{13}$ The trustee takes title to the assets wherever located, and, "subject to the judge's control and the jurisdiction of the commission as provided by the Interstate Commerce Act," may operate the debtor's business. ${ }^{\mathrm{I} 3 \mathrm{a}}$ There are no provisions for a receiver, and it is not even necessary to appoint a trustee. For the approval of the petition vests ${ }^{\mathrm{T}_{4}}$ in the court "exclusive jurisdiction of the debtor and its property wherever located," and the court, by a simple order upon confirmation of the reorganization, may direct that the property be transferred to a new corporation or revested in the old, without the interposition of a trustee..$^{x^{5}}$

By these provisions "friendly" receiverships, with the abuses sometimes attendant upon them, ${ }^{\mathrm{x}}$ and ancillary receiverships, with their accompanying waste, delay and inefficiency, ${ }^{17}$ are completely eliminated. The avoidance of ancillary receiverships alone would justify the new legislation.

After approving the petition the court "shall determine a reasonable time

ro See, for example, S. 939 (the "Norris bill") and S. 937 (the "Attorney General's bill"), $72 \mathrm{~d}$ Cong., ist Sess.

x $\& 77 \mathrm{a}$.

"As shown "in the latest annual report which it has filed with the commission." \$ 77a.

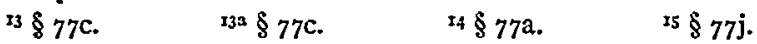

${ }^{16}$ See Harkin v. Brundage, 276 U.S. 36,48 Sup. Ct. 268, 72 L.Ed. 457 (r928); Michigan v. Michigan Trust Co., 286 U.S. 334,52 Sup. Ct. 5I2, 76 L.Ed. II36 (I932).

${ }^{17}$ The conditions are "not only destructive of the assets but of respect for the courts as well." From an address by Solicitor General Thacher, Rep. of Ill. State Bar Ass'n., 339, 343 (I932). 
within which the claims and interests of creditors and stockholders may be filed or evidenced and after which no such claim or interest may participate in any plan except on order for cause shown; the manner in which such claims and interests may be filed or evidenced and allowed, and, for the purposes of the plan and its acceptance, the division of creditors and stockholders into classes according to the nature of their respective claims and interests." 18 This division into classes is a matter of prime importance, for, as will be explained, voting upon the plan is by classes.

When the court has made this determination and the debtor (or the trustee if one has been appointed) has filed a complete list of creditors and stockholders, ${ }^{\text {xa }}$ the commission is ready to begin its share of the work. It begins by holding a public hearing at which plans of reorganization may be presented by the railroad, by the trustee if any, and by creditors representing at least ro\% in amount of the claims of any class. Following the hearing the commission is required to "render a report" recommending a plan, which may or may not be different from any previously proposed. The report will presumably be made public, for the statute provides that upon petition for good cause shown, and upon further hearing if necessary, the commission may modify its recommendations. After the commission has thus finaliy recommended a plan, the plan is submitted to the creditors and stockholders, and any rival plans may be similarly submitted. ${ }^{19}$

If the plan recommended by the commission is accepted by creditors and stockholders in the manner presently to be described, it is certified to the court with the commission's approval and a report of the proceedings. ${ }^{20}$ If some other plan, however, is accepted, the commission holds a further hearing, after which it may approve the plan and certify it to the court or disapprove it. ${ }^{20 a}$ The commission's veto power is absolute. If a plan is not approved within such reasonable time as the court may fix, the court may dismiss the proceedings; ${ }^{22}$ but the court has no power to consider a plan not approved by the commission.

These provisions mark a great departure from the ordinary equity receivership procedure. "Reorganizations," as one expert in the field has said, "2 "always develop into considerable jockeying, often long drawn out, for position among the several classes of creditors and stockholders; and they frequently also become an endurance test wherein the class of security-holders that is willing to wait the longest becomes the pivotal class and stands a good chance of getting the most favorable terms." Under the new legislation, by contrast, the responsibility for going forward is placed upon the commission, whose only interest will be in formulating as promptly as possible an equitable and feasible plan; and while committees of security holders will continue to play an important part, they will no longer dominate the proceedings, and if they delay too long in reaching an agreement the proceedings may be dismissed. ${ }^{23}$

\footnotetext{
${ }^{18} \S 77 \mathrm{c} . \quad{ }^{182} \S 77 \mathrm{c} . \quad{ }^{19}$ The provisions outlined in this paragraph are in $\S 77 \mathrm{~d}$.

20 $§ 77$ f. $\quad 202 \$ 77$ f. $\quad$ 2x Under $\$ 77 \mathrm{c}$.

22 Roberts Walker, Reorganization by Decree, 6 Corn. L. Quar. I54 (I92I).

23 Under $\$ 77$ c.
} 
The activities and power of private interests and of those representing them are further affected by provisions that the fees and expenses of all committees, attorneys, reorganization managers and other agents and assistants, as well as the fees and expenses of the trustee, and of any special masters (who may be appointed by the court only from a standing panel ${ }^{24}$ designated by the Circuit Court of Appeals), may be allowed by the court within maximum limits fixed in each case by the commission. ${ }^{25}$ And these allowances embrace not only amounts to be paid out of the property of the debtor corporation but also amounts to be paid by any transferee corporation after consummation of the plan..$^{26}$ Thus reorganization fees and expenses are brought within the effective control of both the court and the commission - a control which hitherto has been only partial and has sometimes been circumvented in a manner not free from criticism. ${ }^{27}$

When a plan has been finally approved and certified to the court as described above, the court is required to hold a public hearing on notice to creditors and stockholders at which all objections to the plan will be considered whether or not they were previously heard by the commission. ${ }^{28}$ In the House bill, the court's function was limited to a mere consideration of the record made before the commission. Fortunately this provision was eliminated by the Senate, ${ }^{29}$ so that the court may hear de novo both proponents and opponents of the plan. The court, after this hearing, may reject the plan and, "after considering any recommendation which has been filed by the commission," dismiss the proceedings; or confirm the plan if satisfied, among other things, that it "is equitable and does not discriminate unfairly in favor of any class of creditors or stockholders," and that certain classes of dissenters, presently to be described, are adequately protected..$^{30}$

The ordinary equity reorganization terminates in a sale of the assets, being based upon a creditor's bill $;^{3 \mathrm{x}}$ and the only power of the court over the plan of reorganization is an indirect one derived from its power to prevent a sale for less

${ }^{24}$ In the form in which the bill [H.R. I4359] passed the House, it.provided for six special referees to be appointed for six-year terms by the President with the advice and consent of the Senate. The substitute provision for special masters, adopted by the Senate and accepted by the House, was suggested by Solicitor General Thacher. (See his memorandum in 76 Cong. Rec., $72 \mathrm{~d}$ Cong., $2 \mathrm{~d}$ Sess., Appendix p. 29I 2; and see p. 2894.) Referees in bankruptcy have no functions under the bill.

${ }^{25} \$ 877 \mathrm{c}$ and $77 \mathrm{f}$. $\quad{ }^{26} \$ 77 \mathrm{~g}$.

${ }^{27}$ See the remarks of Senator Norris, 76 Cong. Rec., 72d Congress, 2d Sess., 5040, with reference to the Chicago, Milwaukee \& St. Paul Ry. reorganization.

${ }^{28} § 77 \mathrm{~g}$.

29 It was vigorously criticized in the Solicitor General's memorandum cited in note 24 , supra.

$30 \$ 77 \mathrm{~g}$.

${ }^{31}$ The nature of the jurisdiction is thoroughly described in Re Metropolitan Ry. Receivership, 208 U.S. 90, 90 Sup. Ct. I 2 2, 52 L.Ed. 403 (rgo8). 
than a fair upset price..$^{32}$ Resourceful and vigorous judges have in this manner come to exert a considerable pressure in the shaping of a proper plan, and in rare instances have dominated the decisions of the reorganization committees. ${ }^{33}$ But their power rests more upon personality and a capacity for negotiation than upon any legal basis, and in the long run cannot be truly effective in dealing with the "masterful situation" 34 of majorities armed with consents from security holders who too often are merely "dumb sheep." ${ }_{35}$

Under the new legislation, by contrast, the purpose and the end of the proceeding is not a sale of the assets to satisfy claims but the confirmation or disapproval of a plan of reorganization. The court is given direct and absolute power to consider the plan on its merits and to dispose of it accordingly.

If it is true that in equity reorganizations there is no effective control over "masterful" majorities, it is equally true that there is no effective control over obstreperous minorities seeking to capitalize their nuisance value. The court's limited and indirect power to reject an unfair plan does not enable it to compel unruly dissenters to accept a fair plan. And these dissenters cannot be compelled to take securities in the reorganized corporation but may insist upon payment in cash of the value of their interest in the debtor's property-cash which cannot always be raised by the reorganized company..$^{36}$ So it happens that "resourceful minorities with no substantial equities in their position frequently, though losing at every stage of the proceeding, succeed in delaying for years"if indeed they do not entirely block-"reorganizations having the substantially unanimous approval of the security holders and ultimately found by the courts of last resort to be entirely equitable and valid." 37

Under the new legislation all this is changed. The consent of two-thirds in amount of a given class of creditors or stockholders makes the plan, upon confirmation, absolutely binding upon all the creditors or stockholders of that class $3^{38}$ and their respective rights and interests may be modified in any way provided in the plan "either through the issuance of new securities of any character or otherwise." ${ }_{39}$ Complete flexibility is thus provided. Preferred stock or

${ }^{32}$ See Merchants' Loan \& Trust Co. v. Chi. Rys., 158 Fed. 923 (C.C.A. 7th. I907); Guaranty Trust Co. v. Missouri Pacific Ry., 238 Fed. 812, 8I4 (D.C. Mo. Igr6).

33 See Rosenberg, The Aetna Explosives Case-A Milestone in Reorganization, 20 Col. L. Rev. 733 (r920).

${ }^{34}$ Investment Registry, Ltd., v. Chi. \& M. E. R. Co., 212 Fed. 594, 609 (C.C.A. 7 th 1933 ).

${ }_{35}$ As characterized by Mr. Rosenberg in A New Scheme of Reorganization, r7 Col. L. Rev. 523 ( 1917 ).

${ }^{36}$ The cases cannot be considered here, but they are ably discussed in Swaine, Reorganization of Corporations: Certain Developments of the Last Decade, 27 Col. L. Rev. gor (I927), 28 Col. L. Rev. 29 (1928); Rosenberg, Reorganization, the Next Step, 3 Lectures on Legal Topics 3 (r926) (presenting a somewhat different approach).

${ }^{37}$ Swaine, Corporate Reorganization under the Federal Bankruptcy Power, r9 Va. L. Rev. 317,318 (I933).

$3^{38} \& 77 \mathrm{~h} . \quad \quad 39 \S 77 \mathrm{~b}$. 
debentures, for example, may be substituted for mortgage bonds; unsecured claims may be made payable in stock; principal or interest or both may be scaled down; preferred stock may be changed into common; and so on, without limit, subject only to the requirement that the plan shall be equitable. Since securities with a lien prior to any previously issued may be provided for in the plan, adequate security can be given for the new money which is usually necessary to complete the reorganization and provide sufficient working capital. Hitherto, in the absence either of unanimous consent by the holders of mortgage securities, or of payment to the dissenters of the cash value of their claims against the property, there has been no way of giving the new money a prior lien: ${ }^{40}$ and this difficulty has prevented many forms of advantageous reorganizations. Under the new legislation, assuming always that the plan is fair, twothirds in amount of any class of mortgage creditors may compel the entire class, without payment of cash to dissenters, to subordinate their liens to a new prior lien or even to abandon their liens altogether.

It is only in cases where less than two-thirds of a particular class consent that any difficulty is presented. But even then the plan may be confirmed if it provides ${ }^{4}$ for the realization of the value of the claims of the dissenting class in any one of three ways, either $(a)$ by the sale of the property subject to their liens, or (b) by the transfer of their liens to the proceeds of any sale of the property (to be sold at not less than a fair upset price), or (c) by payment in cash of the appraised value of the claims or, at any objecting creditor's election, of the appraised value of the new securities allotted to him under the plan. Thus an equitable plan cannot be blocked even if less than two-thirds of a particular class accept it. In practice, however, it is hardly likely that if the plan is in fact equitable less than two-thirds of any class will withhold consent.

The plan, of course, may not affect at all a particular class of creditors, and in such a case the consent of that class is not required..$^{2}$ Similarly, if the plan provides for full cash payment of the claims of a particular class, the consent of that class is not required..$^{2 a}$

Analogous provisions are made with respect to stockholders. The consent of two-thirds in amount of a class of stockholders binds the class. But if less than two-thirds of the stockholders of a class consent, the plan may nevertheless be confirmed if it provides ${ }^{43}$ for the realization of the value of their equities either (a) by a sale of the property at not less than a fair upset price, or (b) by appraisal and payment in cash of the value of their stock, or, at any objecting stockholder's election, of the value of the securities, if any, allotted to the stock under the plan. Finally, the consent of stockholders is not required at all if the

$4^{4}$ See Guaranty Trust Co. v. Chicago Union Traction Co. $15^{8}$ Fed. 93 I (C.C.A. 6th. 1908); Merchants' Loan \& Trust Co. v. Chicago Rys. 158 Fed. 923 (C.C.A. 7 th. 1907); Hanna et al. v. State Trust Co. et al., 7o Fed. 2 (C.C.A. 8th. I895); Doe v. Northwestern Coal Co., 78 Fed. 62 (C.C.A. Oregon I896); International Trust Co. v. Decker Bros., I 52 Fed. 78 (C.C.A. 9 th. xg07); In re J. B. and J. M. Cornell Co., 201 Fed. 38 I (D.C. N.Y. 19I2).
$4577 \mathrm{~g}$ and $\mathrm{h}$.
${ }^{4} \S 77 \mathrm{e}$.
${ }^{42 a} \S 77 \mathrm{e}$.
$43 \S 77 \mathrm{~g}$ and $\mathrm{h}$. 
court has determined that the corporation is insolvent, or that their interests will not be adversely affected, or that by authorized corporate action the plan has been accepted and they are bound by this acceptance.44

Thus a complete method is provided by which both majorities and minorities will be fairly restrained and at the same time given fair consideration. The only criticism of the statute that might be ventured is that if, as a result of the dissent of a particular class, it becomes necessary to determine a fair upset sale price or the appraised value of securities, the commission is required to make the determination. ${ }^{45}$ This is the only place in the statute where the commission is given power to make final determinations affecting substantive rights. As stated above, if it becomes necessary to determine the corporation's solvency or insolvency the court is required to make that determination,,$^{66}$ and there seems to be no good reason for shifting to the commission the similar and essentially judicial function of fixing upset prices and appraising the value of securities.

After the plan has been accepted and confirmed as described above there is only one further step. The court directs that the property be transferred to a new corporation or revested in the old, as the plan may require. 47 By this simple provision foreclosure proceedings, which hitherto have had to "drag their weary and extravagant length through the court while the plan is being developed," 48 are completely eliminated.

The following miscellaneous provisions may be noted. (I) A subsidiary corporation, or one whose properties are operated by the principal corporation under lease or operating agreement, may join in the proceedings by filing a petition stating that it is insolvent or unable to meet its debts as they mature and that it desires to effect a plan of reorganization in connection with, or as a part of, the plan of the principal corporation. Thereafter the proceedings with respect to the subsidiary or leased road are the same as the proceedings with respect to the principal road.49 (2) A proceeding under the new statute is not made the exclusive remedy for reorganization, as shown by provisions $\mathrm{s}^{50}$ for payment of the fees and expenses of a prior equity receivership (whether brought about before or after the statute takes effect), and for transferring the property, if the proceedings are dismissed without confirmation of a plan, to any equity receiver appointed prior to such dismissal. However, the advantages of the new procedure are so obvious that the courts will doubtless hesitate to act upon creditors' bills for the appointment of receivers, particularly where the bills are brought on the initiative of the debtor. (3) The Secretary of the Treasury is authorized to accept or reject the plan in behalf of any interests or claims of the United States. ${ }^{5 \times}$ This is an important provision, for the Government is a sub-

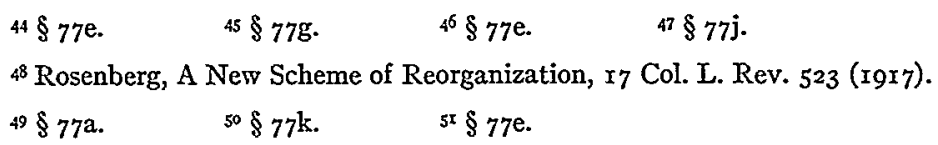


stantial creditor of many railroads ${ }^{52}$ and hitherto the Secretary of the Treasury has had no power to compromise its claims, exchange any of its securities or obligations, or release any collateral.53 (4) By a sweeping provision, claims for personal injuries to employees and claims of personal representatives of deceased employees are made preferred claims against the assets, taking precedence even over first mortgages. ${ }^{44}$ Other provisions are designed to prevent the courts and trustees from changing wages or working conditions, 55 recognizing "yellow-dog" contracts, ${ }^{56}$ or promoting company unions. ${ }^{57}$ (5) The so-called "six-months' rule," giving priority over mortgages to claims for materials or services in connection with maintenance and operation,,$^{8}$ is recognized, and the holders of such claims are treated as a separate class of creditors.59 (6) "Creditors" include the holders of all claims "of whatever character against the debtor or its property, including claims for future rent," whether or not such claims would otherwise be provable under the Bankruptcy Act.60

The chief advantages of the new legislation may be summarized as follows. The jurisdiction of the court is made absolutely certain, and "friendly" proceedings are avoided. Ancillary receiverships and foreclosure proceedings are eliminated. The procedure is expedited by placing primary responsibility for shaping the plan upon a disinterested commission. The power of the court to reject an inequitable plan is made definite and clear. Minorities are bound, and are shorn of their power to delay, cripple or block a proper plan; and adequate security for those furnishing new money may be provided. Fees and expenses are brought within the effective control of the court.

${ }^{2}$ As a result of various provisions of the Transportation Act, 4I Stat. 456, Title II, $\$ \S 202$, 204, 207, 209, 210 (1920).

53 33 Ops. Atty. Gen. 423 (1923); 34 Ops. Atty. Gen. I08 (1924). For several years the Secretary of the Treasury has recommended a grant of such power, to be exercised with the concurrence of the Commission. Annual Reports of the Secretary of the Treasury, 1930, p. 40; 1931, p. 35 ; 1932, p. 32. Bills to that effect were introduced but not enacted in the 71st Cong., $2 \mathrm{~d}$ Sess. [S. 4254, H.R. I 206r], and in the 72d Cong., Ist Sess. [H.R. I0746].

$54 \S 77$ s.

ss ". . . . except in the manner prescribed in the Railroad Labor Act, or as set forth in the memorandum of agreement entered into in Chicago, Illinois, on January 31, 1932, between the executives of twenty-one standard labor organizations and the committee of nine authorized to represent Class I railroads."

${ }^{56} \S 77 \mathrm{q}$.

$57 \S 77 \mathrm{p}$. All of these provisions relating to labor were introduced, as amendments to the bill, by Senator Norris and were adopted without opposition, except that the phrase "yellowdog" was eliminated and a circumlocution adopted in its place. 76 Cong. Rec., $72 \mathrm{~d}$ Cong., $2 \mathrm{~d}$ Sess. 5260 .

${ }_{58}$ Fosdick v. Schall, 99 U.S. 235,9 Ott. 235,25 L.Ed. 339 (1878); Wood v. Guarantee Trust, etc., Co., I 28 U.S. 4I6, 9 Sup. Ct. I3I, $3_{2}^{2}$ L.Ed. 472 (r888); Southern Railway v. Carnegie Steel Co., I 76 U.S. 257,20 Sup. Ct. 347, 44 L.Ed. 458 (I900); Lackawanna, ele., Co. v. Farmers Loan \& Trust Co., 176 U.S. 298,20 Sup. Ct. 347, 44 L.Ed. 475 (r900).
$59 \S 77 \mathrm{c}$.
$60 \$ 77 \mathrm{~b}$. 
The legislation confers more responsibility and power upon the commission than some have thought wise ${ }^{6 r}$ and less than others would have wished..$^{62}$ But it seems to strike a reasonable balance, ${ }^{63}$ and its advantages over the present cumbersome, wasteful, dilatory and only partially effective procedure are numerous and pronounced.

It is to be hoped that Congress will speedily adopt similar legislation relating to the reorganization of industrial corporations. A bill to that effect (drafted by the Solicitor General ${ }^{6}{ }_{4}$ and used as a model for the railroad bill) passed the the House in the last session of Congress, ${ }^{65}$ but due to pressure of time was not

6x The bill was modelled upon S. 492 I introduced on June 2I, 1932 by Senator Hastings. S. 492I merely provided that the plan of reorganization must have the approval of the commission; there were no provisions giving the commission the power to appoint standing trustees, to fix maximum limits for all fees and expenses, to determine upset prices, or to initiate plans.

${ }_{62}$ The first bill introduced by Representative La Guardia, on December 29, I932 [H.R. I3958] removed virtually all power, except a limited power of review, from the court. On January $9, \mathrm{x} 933$ he withdrew this bill and introduced H.R. I4Iro (which passed the House as a part of H.R. r 4359), following the form of the original Hastings bill (note 6r supra) but giving the commission substantially the powers described in note $6 \mathrm{r}$ supra and providing further that the court, in passing on the plan, could act only on the record made before the commission.

${ }_{3}^{6}$ The bill reached its final form only after extended conferences with, and various changes suggested by, Solicitor General Thacher, Senator Hastings; representatives of the commission and of the railroad executives, and many lawyers. See Senator Hastings' statements in 76 Cong. Rec., 72d Cong., 2d Sess., 5०3x, 5034, 5249, 525०.

${ }_{64}$ H.R. 9968, S. 3866 introduced March I, I932 and February 29, 1932 respectively, following the nation-wide inquiry into the Bankruptcy Act conducted by the Department of Justice at the direction of President Hoover. See the Attorney General's report containing the results of this inquiry and the legislation suggested, together with the President's message relating thereto. [Senate Document No. 65, 72d Cong., Ist Sess.]

${ }^{65}$ As a part of H.R. 14359, 72d Cong., 2d Sess. Except for the exclusion of matter relating to the Interstate Commerce Commission, it differed from the railroad bill in only one important particular; it permitted a dissenting lien creditor, even though more than two-thirds of the lien creditors of his class accepted the plan, to insist (if he voiced his objection seasonably) either upon payment in cash of the appraised value of his claim, or, at his election, of the appraised value of the new securities allotted to his claim under the plan, or a sale of the property subject to his lien, or a transfer of his lien to the proceeds of such sale. Under the railroad section, dissenting creditors are given these rights only if less than two-thirds of the class have accepted the plan. Commenting upon this provision, Senator Hastings stated: "There has been much controversy with respect to that provision, though not so much in the case of the railroad section as in the case of the corporate section. To most of us it seems desirable that the two-thirds shall be compelled to bind the one-third. When we come to the corporate reorganization section we have not written such provision in it, because we were afraid to do so, believing that there would be serious objection to it; and I myself do not know whether I am for it or against it." 76 Cong. Rec., 72 d Cong. 2 d Sess., 5034. It is to be hoped that the corporate reorganization bill, when it is acted on, will be modified so as to enable two-thirds to bind the minority, thus harmonizing the procedure with that adopted in the case of railroads, and following the long-established principle of the English Companies Act (note 4 supra). The reorganization procedure will thereby be rendered far more effective; the burden of raising cash for dissenters will be avoided; while the power of the court to disapprove an inequitable or discriminatory plan should be a sufficient safeguard for the minority. 